\title{
Strengthening of Historical Stone Masonry Buildings in Oman using Textile Reinforced Mortars
}

\author{
A.H. Al-Saidy*, A.W. Hago, S. El-Gamal and M. Dawood \\ Department of Civil and Architectural Engineering, College of Engineering, Sultan Qaboos University, Oman.
}

Received 27 August 2015; Accepted 29 June 2016

\begin{abstract}
Most historical buildings and structures in Oman were built using unreinforced stone masonry. Such structures are prone to damage from seismic activity as these structures have negligible resistance to tensile stresses. This paper presents an exploration of the physical and chemical properties of local building materials and the results of experiments with a new strengthening technique using textile reinforced mortar. Limestone and Sarooj were the main building materials used historically in these buildings. Sarooj is a local Omani term for artificial pozzolana produced by calcining clays. Two mortar mixes were developed, one as the jointing mortar and the second as the matrix mortar. The second part of the study consisted of the construction of three masonry walls and two columns of $0.35 \times 0.25 \times 1.2 \mathrm{~m}$ (width $\mathrm{x}$ depth $\mathrm{x}$ height). The three walls were strengthened using externally bonded textiles using three different combinations of mortar and textile. One column specimen was kept as a control and the other was fully wrapped with carbon textile reinforced mortar. The walls were tested under out-of-plane four-point bending. All the wall specimens showed a significant improvement in strength up to three times its self-weight and reasonable deformation before failure. The column specimens were tested under axial compression. The failure load and displacement of the strengthened columns increased by seven and three times, respectively, compared to the control column.
\end{abstract}

Keywords: Strengthening, Historical, Stone masonry wall, Textile reinforced mortar, Rehabilitation.

$$
\begin{aligned}
& \text { تعزيز المنشآت التاريخية المبنية من الحجارة يخ عمان باستخدام الصاروج المقوى بالألياف }
\end{aligned}
$$

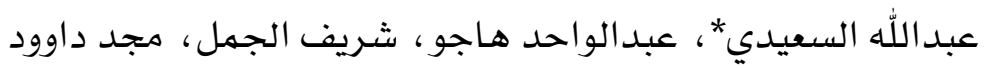

* Corresponding author's email: alsaidy@squ.edu.om 


\section{Introduction}

Oman has a long and rich history that has defined every aspect of its culture. In standing witness of this civilization, there exists a great number of historical buildings distributed all over the country. A variety of historical, geographical, social, and economic events has influenced the Omani building style, both from structural and architectural perspectives. These historical buildings are of great value to Oman as they highlight the development of Omani civilization over the years from social, cultural and economic points of view, which when combined contribute to the current Omani identity. Preserving these buildings is a national duty to keep Omanis linked to their history (Ministry of Heritage, 1994).

An inspection of Oman's historical buildings indicates that Omanis of the past utilized locally available materials in their buildings due to their low cost and compatibility with the surrounding environment (Al-Mashani 1997). Oman is a relatively large country with significant variations in topography, geography, geology, and climate. These variations influenced the materials used, and unique methods of construction followed. The importance of the buildings and their intended uses were major factors in the selection of the materials and construction methods.

Unreinforced masonry walls (URM) are the main load-carrying elements in Oman's historical buildings. These walls are limited in their ability to withstand compressive vertical loads (Bernat-Maso et al. 2014). Unreinforced masonry walls are prone to damage from seismic activity, which produces in-plane and out-of-plane loadings. Therefore, masonry walls need to be strengthened for both flexure and shear loads. Due to the recent threat of seismic activity in the region, Oman's structures may be subjected to tensile forces. Therefore, solutions for strengthening these structures are crucial. The walls in historical structures are typically constructed with stones or mud bricks and bonded with locally produced mortar made by mixing Sarooj, lime, and water. Sarooj is an Omani term for artificial pozzolana produced by calcining clays. Calcined clay mixed with lime and water has been used as a cementing material for a long time (Al-Rawas and Hago 2006). In addition, unreinforced masonry columns are critical members in Omani historical buildings and require upgrading to enhance their axial compressive strength.

Various conventional methods have been used for strengthening masonry walls such as the construction of single or double jackets made of steel-reinforced shotcrete or cast-insitu concrete and grout injections (Ehsani et al. 1997; Triantafillou 1998). These methods may be problematic due to the extra weight added to the building that increases the threat of failure under cyclic loading. Such reinforcement has drawbacks, including the eventual deterioration of steel reinforcement due to corrosion, the need for large site work and scaffolding, and the effect on the appearance of the building which does not preserve the architectural value of the historical buildings (Ehsani et al. 1997; Triantafillou 1998).

The application of fiber reinforced polymers (FRP) in upgrading and reinforcing civil engineering structures has received special attention in recent years due to FRPs' favorable properties and their extremely high strengthto-weight ratio, corrosion resistance, ease and speed of application, and minimal change in the geometry. FRP composites are made of fibers (carbon, glass, and aramid) held by polymer resin (epoxy, polyester, or vinyl ester). The conventional method of applying FRP composites involves bonding them to previously prepared surfaces (concrete or masonry) by means of an epoxy resin. However, this technique has a few drawbacks which are attributed to the resins used to bind or impregnate the fibers. These drawbacks include poor behavior of epoxy resins at high temperatures; the requirement of special and expensive fire protection measures; the relatively high cost of epoxies; a lack of vapor permeability, which may cause damage to the concrete or masonry structure, and the incompatibility of epoxy resins and substrate materials (Harajli et al. 2010; Kolsch 1998; Papanicolaou et al. 2011; Pinho et al. 2014).

The solution to overcome the drawbacks associated with these physicochemical incompatibilities (water-vapor permeability) is to replace the epoxy resin with an inorganic 
binder such as cement-based mortars. Furthermore, in order to ensure a good matrixcore adhesion, grid textiles may replace continuous fiber sheets. This composite material based on textiles embedded in a mortar matrix is known as textile reinforced mortar (TRM).

Kolsch (1998) performed a study of strengthening URM walls with fiber reinforced mortar (FRM). In his study, full scale masonry walls constructed from sand-lime bricks and strengthened with a carbon fiber cement matrix system (three layers of unidirectional carbon textile in a polymer-modified cement binder) were tested under out-of-plane loading. Cyclic horizontal loading and unloading was exerted on the walls using a pressurized air bag. The wall systems exhibited a considerable increase in the out-of-plane bending capacity compared with the unstrengthened walls.

Harajli et al. (2010) investigated URM walls strengthened with textile reinforced mortar. Specimens $(\mathrm{N}=25)$ were constructed of different stones-hollow block, brick, and sandstone-bonded by a mortar. Textile meshes made out of either bitumen-coated Eglass fibers (coated to provide an alkaline resistance) or coated/uncoated basalt fibers were attached to the tension surface by mortar, which was either lime mortar of normal and high strengths or cement-based mortar. Regardless of the causes of failure, TRM walls resulted in a considerable increase to their outof-plane flexural and displacement capacities when subjected to static loading.

Papanicolaou et al. (2011) investigated the effectiveness of TRM jacketing for out-of-plane loading of masonry specimens. The main parameter explored in the investigation was the number of grid layers used to form the jackets (one or two layers, applied on both sides for all specimens). The results indicated that even the weakest TRM configurations (low-grade textiles combined with low-strength mortars), when adequately anchored, resulted in a more than $400 \%$ increase in strength and a $130 \%$ increase in deformability.

Pinho et al. (2014) worked on strengthening rubble stone masonry walls. This strengthening solution used three-dimensional (3D) ties comprising zinc coated steel wires and a textile reinforced mortar rendering (composed of a 30 mm layer of lime, cement, and sand [1:1:6] mortar, reinforced with glass fiber mesh) applied to both sides of the specimens. Specimens were subjected to axial compression force. Results indicated an up to three times improvement in both compressive strength and stiffness of the strengthened walls relative to the unstrengthened walls. However, the ductility of the walls was not improved. Buckling was observed in all strengthened walls. Nevertheless, the nature of failure was significantly improved as complete collapse did not occur compared to the reference walls. The strengthening system was also found to be compatible with the masonry walls in terms of porosity, permeability and water capillary.

To preserve Omani historical buildings using compatible materials, local materials should be used as much as possible. To implement advance strengthening techniques such as TRM, mortar made from Sarooj was used since this material had been used in the original construction of such historical structures. Hago and Al-Rawas (1997) indicated that Sarooj properties are dependent on the mineral composition of the clay used in terms of the reactive silica and alumina composition. The binding nature of Sarooj results from its reactive silica and alumina reaction with lime and water to produce calcium silicates and aluminates hydrates similar to those in Portland cement and high aluminate cement, respectively. Sarooj's burning temperature and duration was found to influence the pozzolanic-reactivity of the resultant Sarooj.

Hago et al. (2002a) indicated that Sarooj's reactivity is not only a function of its chemical composition and burning conditions but also of its physical properties, including particle size distribution, density, shape, and fineness, which also influence the Sarooj properties. It was observed that increasing the Sarooj-lime mixture's fineness increased the compressive strength and decreased workability and setting times.

Hago et al. (2002b) investigated different curing conditions on the compressive strength of Sarooj-cement mixes. It was found that for the prevailing climate conditions in the Gulf 
region, sun and air curing are the best to expedite the strength that can be gained from Sarooj mortars. In the same study, the optimum sand/Sarooj and cement/Sarooj ratios were also investigated for a variety of mixes. The study concluded that a sand/Sarooj ratio of 0.3 and a cement/Sarooj ratio of 0.6 represent the optimum ratios that provide the highest compressive strength for all mixes.

The experimental work presented is a pilot study in the strengthening of historical buildings through construction and strengthening of representative elements of walls and columns. To the authors' knowledge, this is the first study that deals with strengthening local Omani historical buildings. The study consisted of a collection of lime stones and Sarooj and conducting chemical analysis and physical tests to determine various properties of the materials. Scaled masonry walls and columns were then constructed. Strengthening schemes were applied to these elements using glass fiber and carbon fiber textiles bonded with compatible mortar made of Sarooj. Out-of-plane loading was used to test strengthened walls while axial compression was used to test columns.

\section{Material Characterization}

\subsection{Stone}

Limestone is defined according to the American Society for Testing and Materials (ASTM) Standards C51 (2011) as an initially sedimentary rock consisting mainly of calcium carbonate or of the carbonates of calcium and magnesium. Limestone may be high in calcium, magnesium, or dolomiticas. Due to limestone's wide availability, its ease of cutting, its good heat and humidity insulation, and its aesthetics, it was widely used historically in Oman's historical buildings. The limestone used in this study was obtained from Wadi AlKhoud, and the stones were crushed to fragments of random sizes (Fig. 1a). The stone was verified to be limestone by applying hydrochloric acid $(\mathrm{HCl})$ and listening for a strong fizzing to occur due to the $\mathrm{CO}_{2}$ produced from the reaction of $\mathrm{HCl}$ with $\mathrm{CaCO}_{3}$ (Fig. 1b). A sample of the limestone crushed into particles and passed through a sieve sized $0.075 \mathrm{~mm}$ was prepared for chemical analysis. ASTM Standard C 25-11 procedures were followed to determine its chemical composition. Limestone's main chemical constituents are summarized in Table 1.

The stone's uniaxial compressive strength was measured in accordance with ASTM Standard D7012 (2004). In this test, 10 cores of $37 \mathrm{~mm}$ diameter and $80 \mathrm{~mm}$ in height were extracted from random limestone samples. Compressive load was applied through two circular plates at a rate of $0.5 \mathrm{kN} / \mathrm{s}$ until failure occurred. The average compressive strength was found to be $50 \mathrm{MPa}$ for the air-dried limestone cores. Water absorption of the stones was determined following ASTM Standard

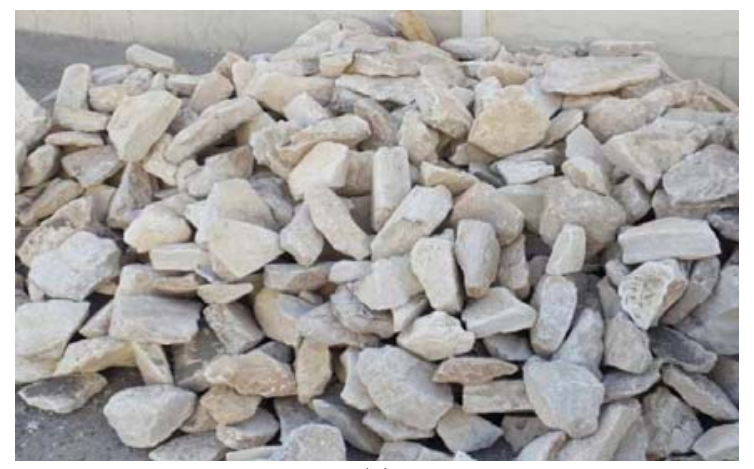

(a)

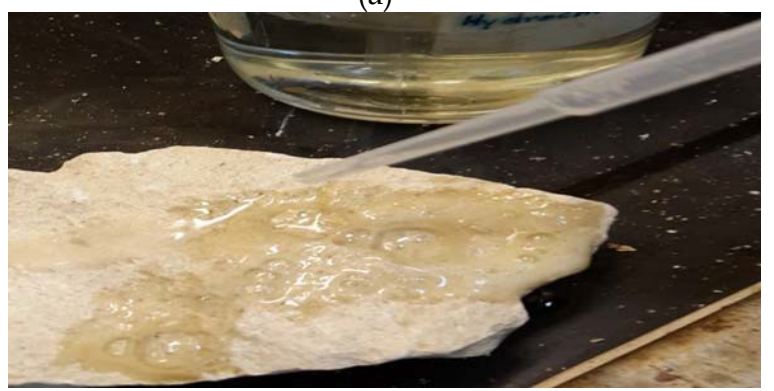

(b)

Figure 1. a) Limestone, b) Limestone reaction with $\mathrm{HCl}$.

Table 1. Main chemical compounds of limestone and Sarooj.

\begin{tabular}{lcc}
\hline Compound & $\begin{array}{c}\text { Limestone } \\
(\%)\end{array}$ & $\begin{array}{c}\text { Sarooj } \\
(\%)\end{array}$ \\
\hline $\mathrm{CaO}$ & 39.99 & 28.92 \\
$\mathrm{SiO}_{2}$ & 3.18 & 21.46 \\
$\mathrm{Al}_{2} \mathrm{O}_{3}$ & 0.59 & 6.49 \\
$\mathrm{Fe}_{2} \mathrm{O}_{3}$ & 6.61 & 3.66 \\
$\mathrm{MgO}$ & 1.5 & 3.28 \\
$\mathrm{LOI}$ & 41 & 27.51 \\
\hline
\end{tabular}


D6473 (2010). The stones were weighed after they had been soaked in water. The stones were later oven dried and weighed. Water absorption was then calculated and found to be $2.1 \%$.

\subsection{Sarooj}

Sarooj is a traditional Omani construction material and a main component of historical buildings, especially those made of stones. Sarooj is manufactured by subjecting clay to the calcination process. Previous studies have identified different factors that affect the reactivity of Sarooj, including physical, mechanical, chemical, and geotechnical properties.

The Sarooj used in this study was obtained from the Ministry of Heritage and Culture (MHC) where it was produced in the Nakhal Sarooj factory following traditional production methods. Nakhal-produced Sarooj is used extensively in the restoration work of historical buildings administered by MHC. A sample of Sarooj passing $0.075 \mathrm{~mm}$ was prepared for chemical analysis. Standard procedures were followed to determine its chemical composition (ASTM C 114-13). The chemical analysis data is an important indicator of the Sarooj pozzolanic activity. Sarooj's main chemical constituents are summarized in Table 1. Three major components $-\mathrm{SiO}_{2}, \quad \mathrm{Al}_{2} \mathrm{O}_{3}$ and $\mathrm{Fe}_{2} \mathrm{O}_{3}-$ constitute $31.61 \%$ of the Sarooj. ASTM Standard C618 and Indian Standards (Varshney 1982) require that, for a good pozzolana, the total of the three components should be greater than 70 and $50 \%$, respectively. From the chemical composition alone, it seems that the Sarooj is not likely to have high pozzolanic activity. The chemical composition depends on the source of the calcined clay and the calcination process (temperature, duration etc.). The latter is not well controlled in the traditional method of producing Sarooj (Al-Rawas and Hago 2006).

\subsection{Jointing Mortar}

Historical data indicate that mixtures of coarse Sarooj, sand, and water were used to bind stones in the construction of Omani masonry structures. Workability was the main parameter in designing the mix as no historical records of the exact mix proportions is available. In the current study, Sarooj passing through a $4.75-\mathrm{mm}$ sieve was used along with coarse normal sand passing through a five-mm sieve and water with proportions of 2:1:0.67, respectively. The slump for the mix was found to be $85 \mathrm{~mm}$. The mix was prepared and cast in $70.7 \times 70.7 \times 70.7 \mathrm{~mm}^{3}$. The cubes were removed from the mold after 24 hours and left to cure in the air under lab temperatures of 20 $22^{\circ} \mathrm{C}$ for 28 days before testing under compression.

Three cubes were tested under uniaxial compression at a rate of $0.25 \mathrm{~mm} / \mathrm{min}$ for 28 days for compressive strength. The average 28 days' compressive strength was found to be $0.76 \mathrm{MPa}$. The long setting time and low strength is mainly attributed to the low pozzolanic activity of the Sarooj produced by traditional methods as indicated by chemical compounds - mainly $\mathrm{SiO}_{2}, \mathrm{Al}_{2} \mathrm{O}_{3}$, and $\mathrm{Fe}_{2} \mathrm{O}_{3}$ as discussed in Section 2.2. This also requires a long curing period for the Sarooj to gain strength as reported in several studies (AlRawas and Hago 2006; Hago and Al-Rawas 1997; Hago et al. 2002a; Hago et al. 2002b).

\subsection{Matrix Mortar}

In order to bond the textiles to the stone masonry specimens, and develop adequate bonding strength, durable and compatible mixes for plastering were developed. Since this was to be applied externally to an existing structure, some modification in the Sarooj mix to enhance the bonding strength was determined to be acceptable, but this could not be done in the joining mortar as it was considered to be part of the existing condition of the historical structure. The optimum design mix ratios of Sarooj, sand, and cement to produce the maximum strength were adopted from a study by Hago et al. (2002b). A sand: Sarooj ratio of 0.3 and cement/Sarooj ratio of 0.6 were used in the matrix mortar. To enhance the strength and bond properties of the matrix mortar, very fine Sarooj and sand were used. Accordingly, two mixes of Sarooj and cement, and sand and water were prepared using normal and dune sand alternatively. The first mix (M1) was made of Sarooj: cement: sand: water with proportions of 1:0.6:0.3:0.52 using dune sand and Sarooj, both of which passed through a $0.3-\mathrm{mm}$ sieve. The second mix (M2) was prepared with Sarooj: cement: sand: water in proportions of 1:0.6:0.3:0.5 using normal sand passing through a $0.6-\mathrm{mm}$ sieve and Sarooj passing through a $0.3-\mathrm{mm}$ sieve. Cubes of $70.7 \times 70.7 \times 70.7 \mathrm{~mm}$ were cast, removed after one day from the molds and kept under 
air curing at a laboratory temperature of 20$23^{\circ} \mathrm{C}$ for 28 days before testing in compression. Prisms of $100 \times 100 \times 500 \mathrm{~mm}$ were cast, removed from the molds after one day and air cured under laboratory temperatures for 28 days in order to be tested for flexural tensile strength.

Both mixes resulted in an equal slump of 70 $\mathrm{mm}$. Mix M1 yielded an average 28 days compressive and flexural tensile strengths of 14.77 $\mathrm{MPa}$ and $1 \mathrm{MPa}$, respectively. Mix M2 resulted in average 28 days compressive and flexural tensile strengths of $18.12 \mathrm{MPa}$ and 1.21 $\mathrm{MPa}$, respectively. Normal sand matrix mortar (M2) showed slightly higher compressive and flexural tensile strength compared to the dune sand matrix mortar (M1), which may be attributed to the granular surface of the normal sand compared to the smooth surface of the dune sand.

\subsection{Textile}

Carbon fiber (CF) and glass fiber (GF) bidirectional textiles were used for the strengthening of the specimens. CF textile has a roving dimension of $1.1 \mathrm{~mm}$ wide by $0.5 \mathrm{~mm}$ thick in the longitudinal direction with $12 \mathrm{~mm}$ spacing between the rovings; and a $0.5 \mathrm{~mm}$ wide by 0.5 $\mathrm{mm}$ thick dimension in the transverse direction with $6 \mathrm{~mm}$ spacing between the rovings. GF textile has a roving dimension of $1.3 \mathrm{~mm}$ wide by $0.5 \mathrm{~mm}$ thick in both directions and spacing between the rovings of an average of $5 \mathrm{~mm}$ in both directions (Fig. 2).

The textile was characterized in a laboratory by means of uniaxial tensile tests according to ASTM Standard D5034-09 (2013). Textile fibers specimens were cut into $220 \mathrm{~mm}$ lengths and 80 $\mathrm{mm}$ widths to fit the testing machine (Fig. 3). The test was done on a load control rate of 10 $\mathrm{kN} / \mathrm{s}$. Table 2 shows the tensile test results of the textile specimens reported as an average value of three test samples. The peak load $\mathrm{F}$ is reported in $\mathrm{kN} / \mathrm{m}$ as a force per unit width based on the $80 \mathrm{~mm}$ width and strain $\varepsilon$ defined as the elongation of the specimen at peak load relative to the original length of the specimen.

\section{Stone Masonry Specimens Cons- truction and Test Setup}

Five specimens were constructed: three walls and two columns. The dimensions of the specimens were $0.35 \times 0.25 \times 1.2 \mathrm{~m}$ (width $\mathrm{x}$

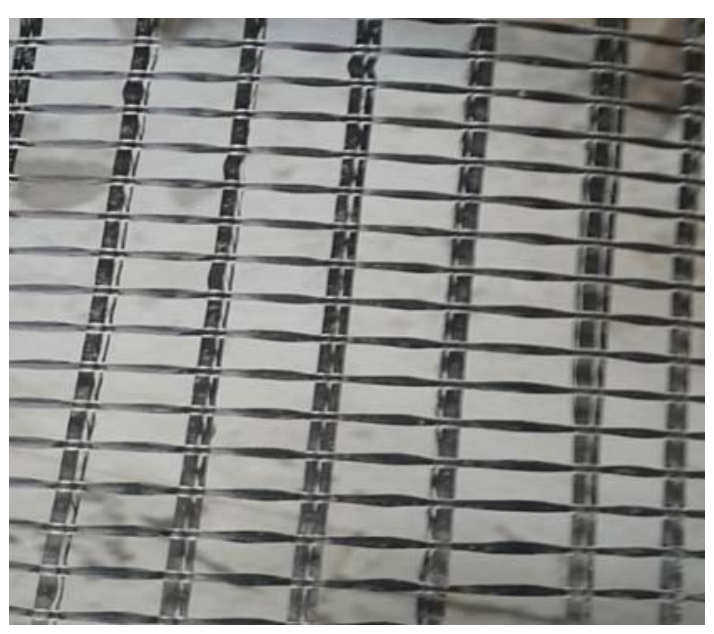

(a)

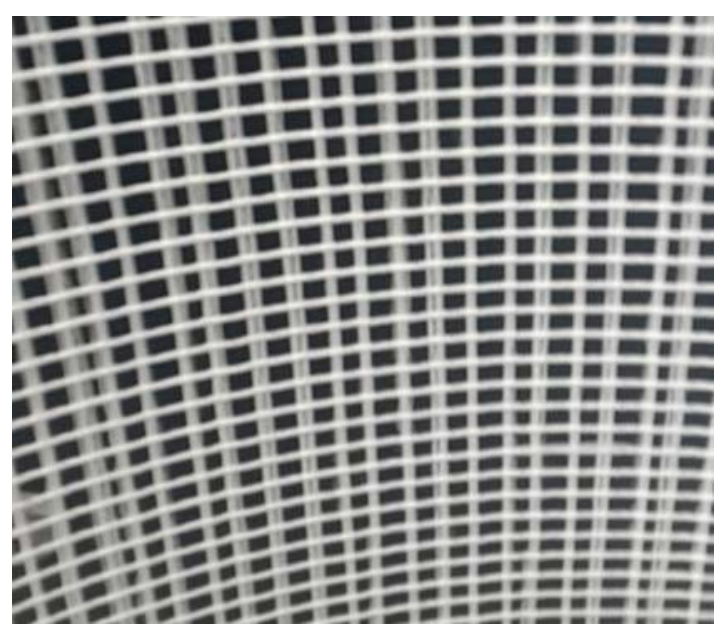

(b)

Figure 2. a) Carbon fiber textile, and b) Glass fiber textile.

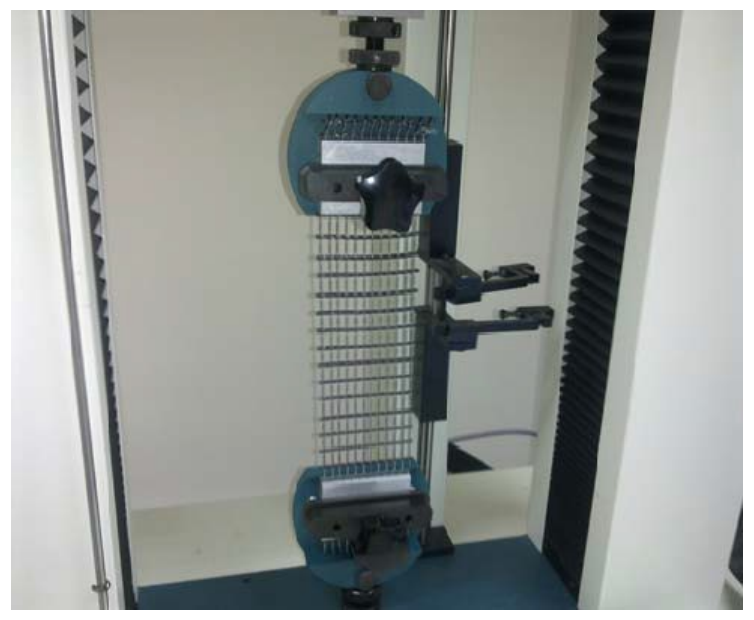

Figure 3. Photograph of pure tensile tests of textile specimens. 
depth $x$ height). A professional stone mason was hired to construct the specimens. The walls and columns were constructed using an assembly of limestone bonded by Sarooj mortar. The specimens were constructed over a wooden platform covered by a polyethylene sheet for easy mobilization of the specimens during testing. They were constructed vertically in two phases: the layers of stones and mortar constructed to a height of $0.6 \mathrm{~m}$ and then left for the mortar to set to avoid squeezing the mortar at the lower layers. Stones were cut into appropriate sizes and arranged in layers, and mortar was used to bind them together (Fig. 4). The constructed specimens were left to air cure for 60 days.

Table 2. Textile tensile properties.

\begin{tabular}{lcc}
\hline Textile & $\begin{array}{c}\mathrm{F} \\
(\mathrm{kN} / \mathrm{m})\end{array}$ & $\begin{array}{c}\varepsilon \\
(\%)\end{array}$ \\
\hline Carbon & 35 & 4 \\
Glass & 25 & 6 \\
\hline
\end{tabular}

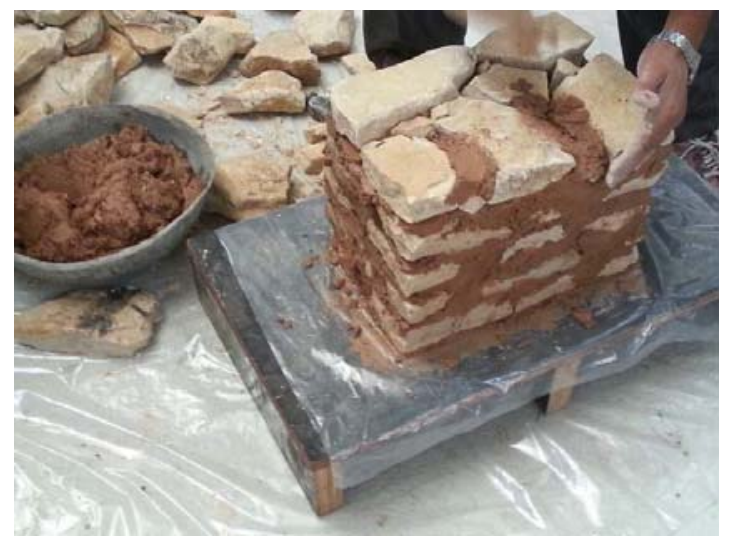

(a)

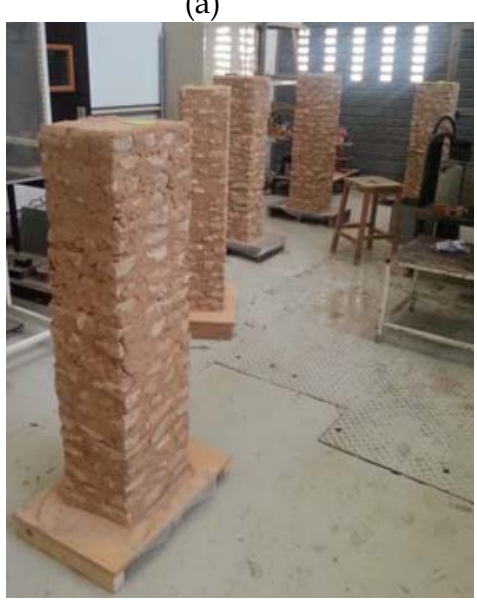

(b)

Figure 4. (a) Construction of stone masonry specimens, (b) Specimens air curing after construction completion.

\subsection{Strengthening of Wall Specimens}

After the specimens had been cured for almost 30 days, walls were strengthened with a bonding textile on the tension side. Carbon fiber and glass fiber textiles were used in combination with two matrix mortars (Table 3). The specimens were cleaned and rubbed to even the surface and increase the bond with the matrix mortar or plaster. The surfaces to be plastered were sprayed with water prior to plastering to maintain the water content in the plaster mortar. After the face of interest had been prepared, a layer of plaster mortar of 1-2 $\mathrm{cm}$ was applied, and then the textile was bonded on the surface, pushed into the plaster layer, and surfaced with a thin plaster layer to fix it in place. Then a second layer of mortar of $1-1.5 \mathrm{~cm}$ was applied. The variation in the plaster or mortar thickness was due to the uneven surface of the wall. Figure 5 shows a schematic representation of the strengthening procedure. The specimens after application of the textile were kept for 28 days under air curing at laboratory temperatures before testing.

\subsection{Strengthening of Column Specimens}

Two columns were constructed: one specimen was used as a reference specimen while the other was strengthened by fully wrapping carbon fiber textile around the perimeter of the whole column (Table 3). Carbon has a higher stiffness (stress/strain ratio) compared to glass. The confinement effect is more efficient using carbon fiber as the fibers reach higher stresses at relatively small strain compared to glass fiber. The

Table 3. Specimens' designation and description.

\begin{tabular}{ll}
\hline Designation & \multicolumn{1}{c}{ Description } \\
\hline \multirow{2}{*}{ WGM1 } & $\begin{array}{l}\text { Wall strengthened by Glass } \\
\text { Fiber Textile using Dune } \\
\text { Sand Mortar (M1) }\end{array}$ \\
& $\begin{array}{l}\text { Wall strengthened by Glass } \\
\text { WGM2 }\end{array}$ \\
& $\begin{array}{l}\text { Fiber Textile using Normal } \\
\text { Sand Mortar (M2) }\end{array}$ \\
WCM2 & $\begin{array}{l}\text { Wall strengthened by Carbon } \\
\text { (M2) Textile using Mortar }\end{array}$ \\
CC & Control Column \\
CCM2 & Fully Wrapped Column using \\
& Carbon Textile with Mortar \\
& (M2) \\
\hline
\end{tabular}




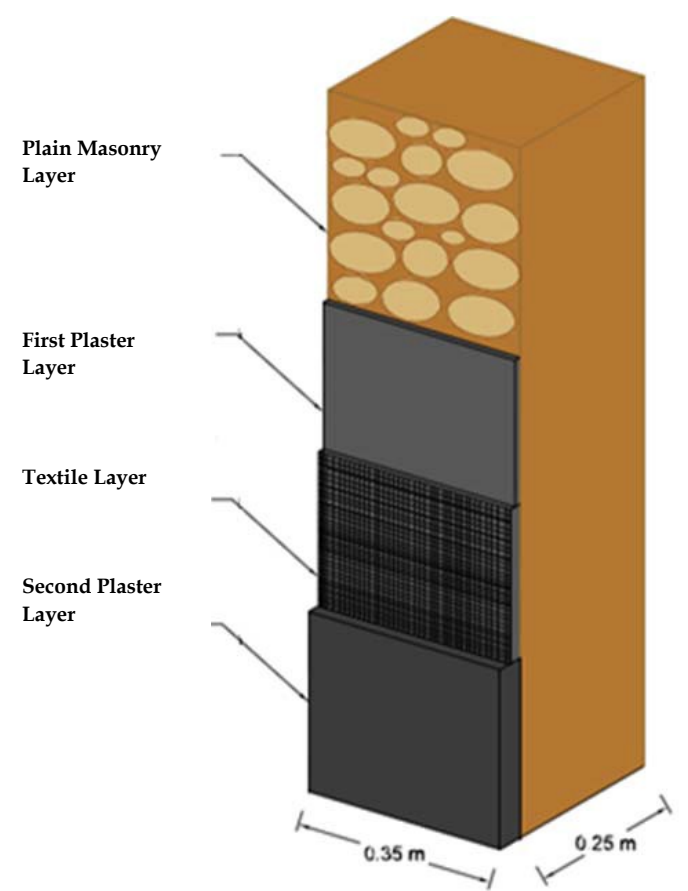

Figure 5. Schematic representation of strengthening procedure for walls.

strengthening of the column followed a similar procedure as in the wall specimens, except that for the column the process was done on the four sides of the column. A first layer of plaster mortar in the range of 1-2 cm was applied on two adjacent faces, and then the textile was bonded on the plastered area. It was pushed into the plaster layer and surfaced with a thin plaster layer to fix it. The same procedure was repeated for the other two faces. The textile was overlapped on the first face to the center of this face to ensure full confinement around the column. A second layer of plaster of 1-2 cm was then applied around the perimeter of the column. The sequence of bonding the textile is shown in Fig. 6. The column was then capped on top with the same mortar to level the surface for later axial load application. The strengthened specimen was kept for another 28 days under air curing at laboratory temperatures before testing.

\subsection{Test Setup}

The three wall specimens were tilted and flipped such that the strengthened face was at the bottom and transported to the testing area. All wall specimens were tested under out-ofplane four-point bending. The specimens were simply supported with span length in between supports of one meter (Fig. 7). At the wall's mid-span, two displacement transducers were placed to measure deflection at both sides of the wall. Loading was then applied using a 250 $\mathrm{kN}$ compression actuator at a rate of 1 $\mathrm{mm} / \mathrm{min}$ until failure.

The columns were tested under axial compression. The columns were capped with a rubber sheet followed by a steel plate. A compression load was then applied using a $4000 \mathrm{kN} \mathrm{UTM}$ at a rate of $2 \mathrm{~mm} / \mathrm{min}$ until ultimate load was reached. The load and displacement at the top of the column were recorded. The test setup is shown in Fig. 8.

\section{Test Results and Discussion of Stre- ngthened Stone Masonry Elements}

\subsection{Strengthened Wall Specimens}

The load versus mid-span deflection for the strengthened walls is shown in Fig. 9. As can be noted, there are multiple load peaks in each curve in all strengthened walls' behaviors. All the wall specimens failed due to diagonal shear adjacent to the supports within the shear span (Fig. 10). Cracks developed diagonally between the support and the loading point and, were expanded until a separation of the masonry wall occurred. As diagonal cracks developed, a drop in the applied load was observed. Then the load picked up again with further deflection with an increase in wall curvature causing cracks and gaps to come closer to enhancing the interlocking action of the limestone and further increase in the applied load. The diagonal shear failure in all walls was due to the weak Sarooj jointing mortar, which has very low strength as discussed in Section 2.3. No failure in the textile or the matrix mortar was observed. All textile types and matrix mortar performed well in terms of tensile and bond strength, and all failures were caused by the weak jointing mortar. Nevertheless, all strengthened walls attained high strength and ductility when compared to plain or unreinforced masonry walls. The bending moment due to the loading scheme used in the test of the walls caused tensile stresses at the bottoms of the walls, which was entirely resisted by the textile layer at the bottom of the strengthened wall. However, unreinforced masonry wall will fail when subjected to tensile stresses as a result of 


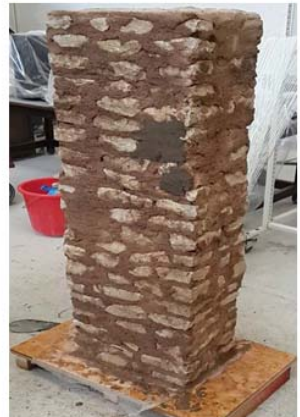

(a)

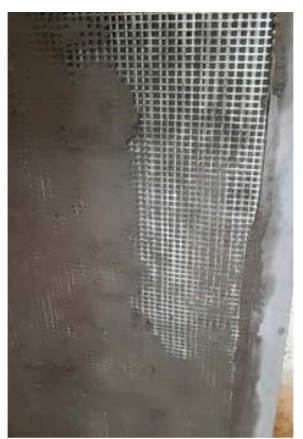

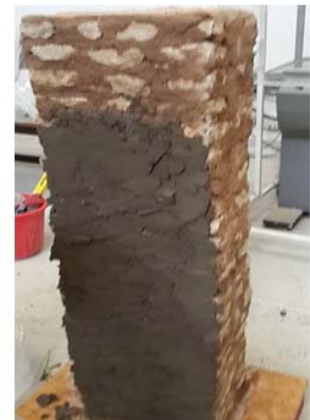

(b)

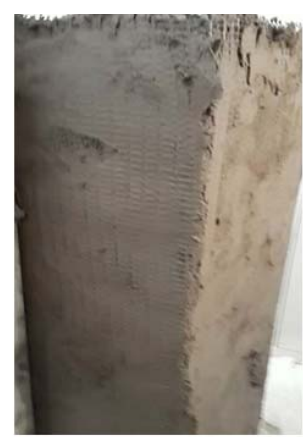

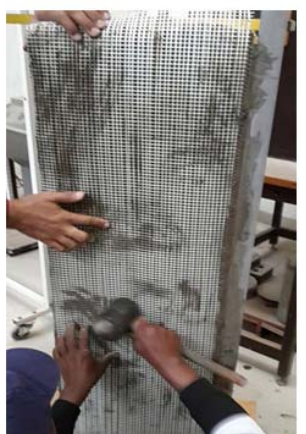

(c)

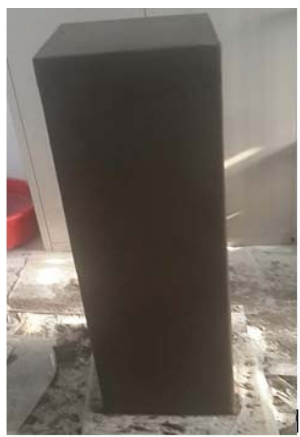

(f)

Figure 6. Stages of column strengthening: (a) wetting of the masonry surtace replaced by, (b) Applying the first mortar layer, (c) Bonding the textile, (d) Fixing the textile with thin mortar layer, (d) Applying the second mortar layer, and (f) Finishing up the surface and capping the column.
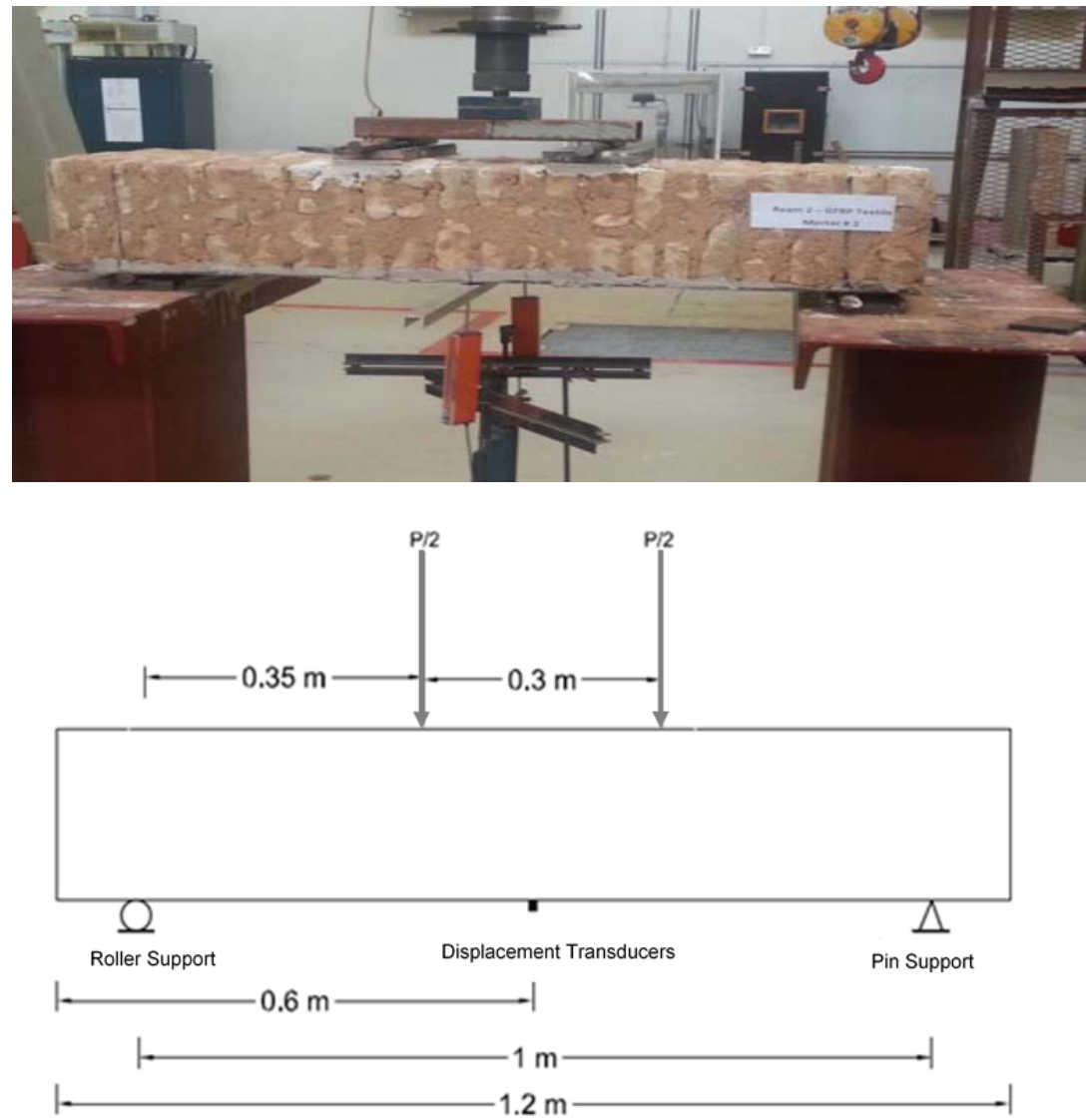

Figure 7. Walls test setup. 

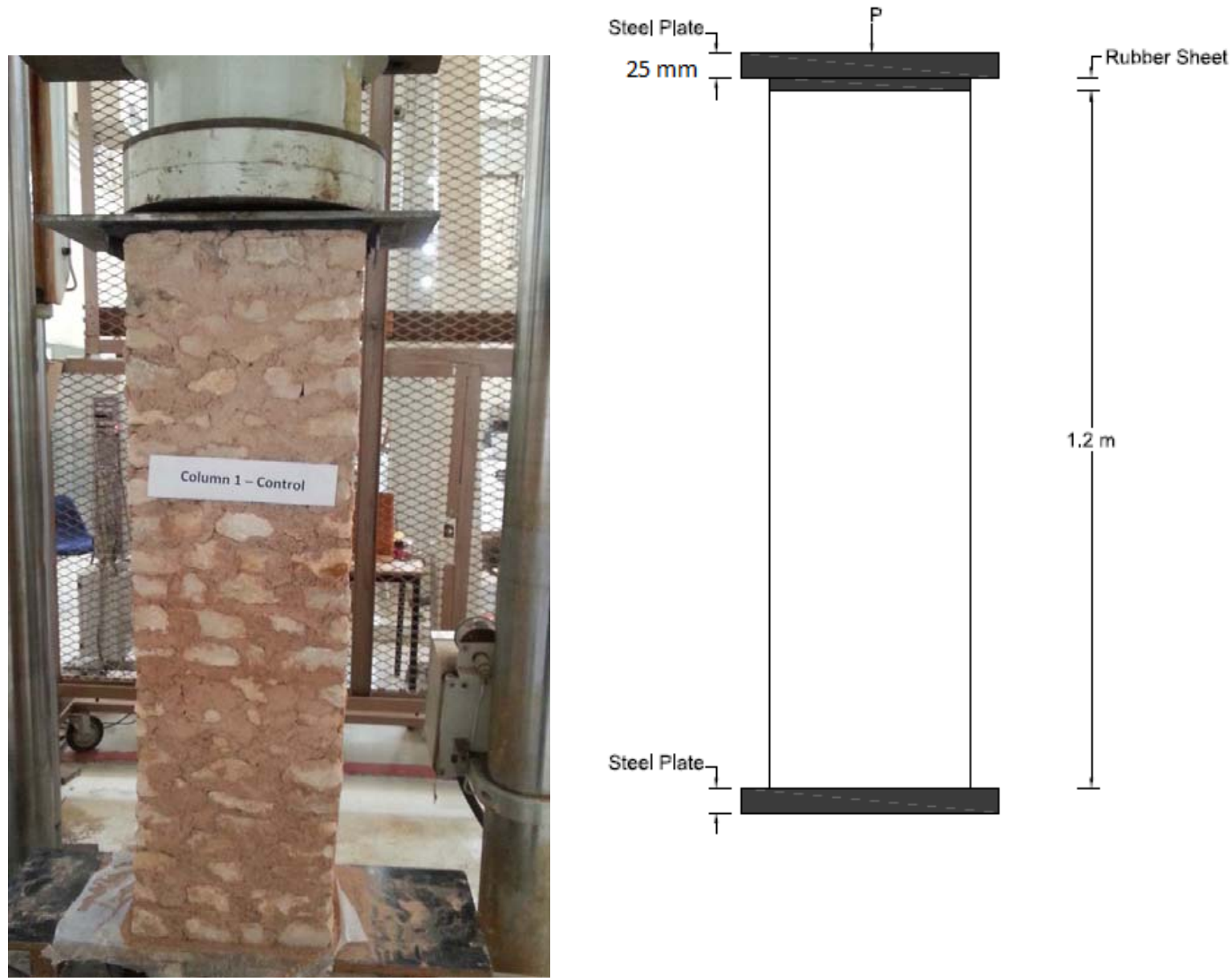

Figure 8. Columns test setup.

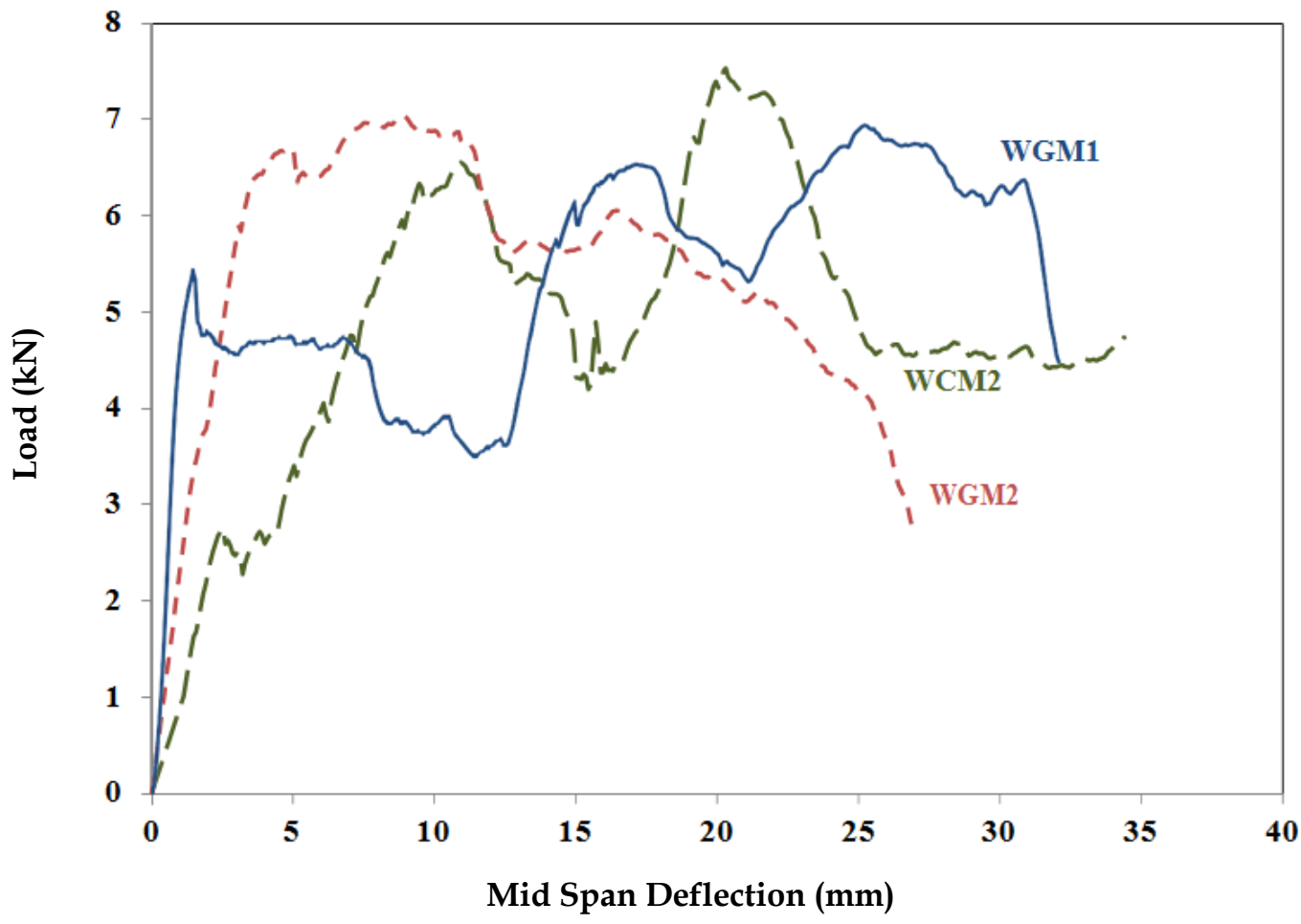

Figure 9. Load vs. Mid span Deflections for the tested walls. 


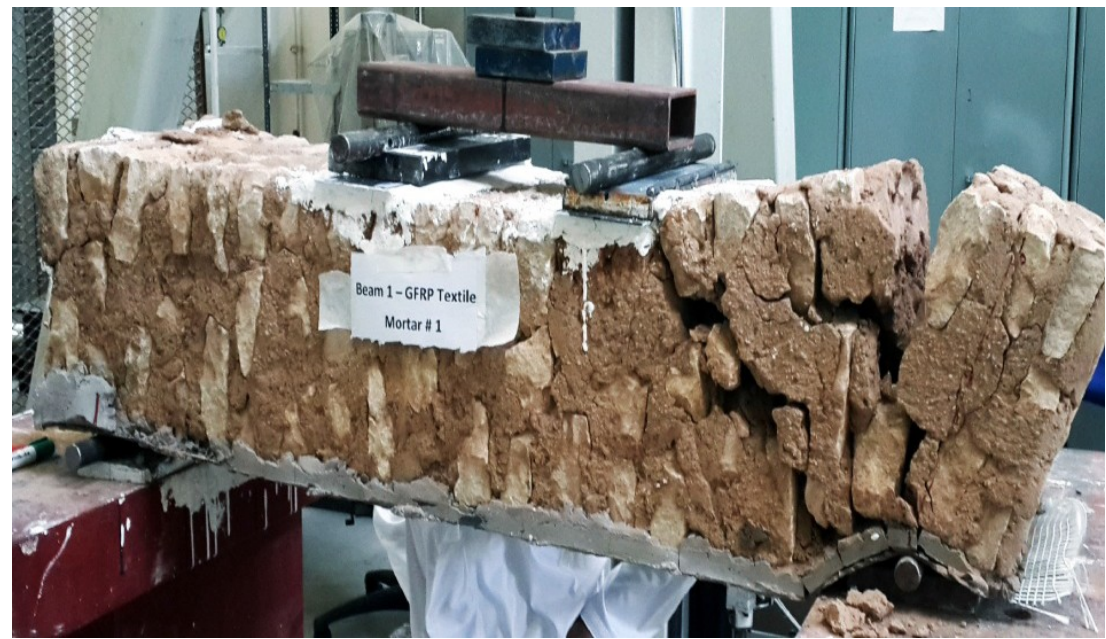

(a)

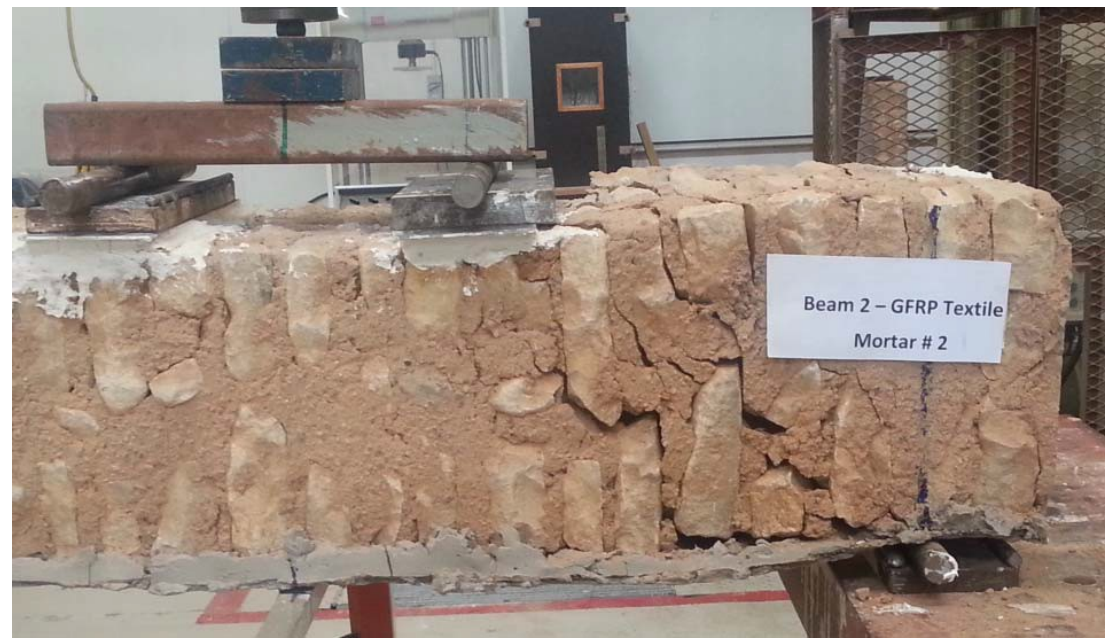

(b)

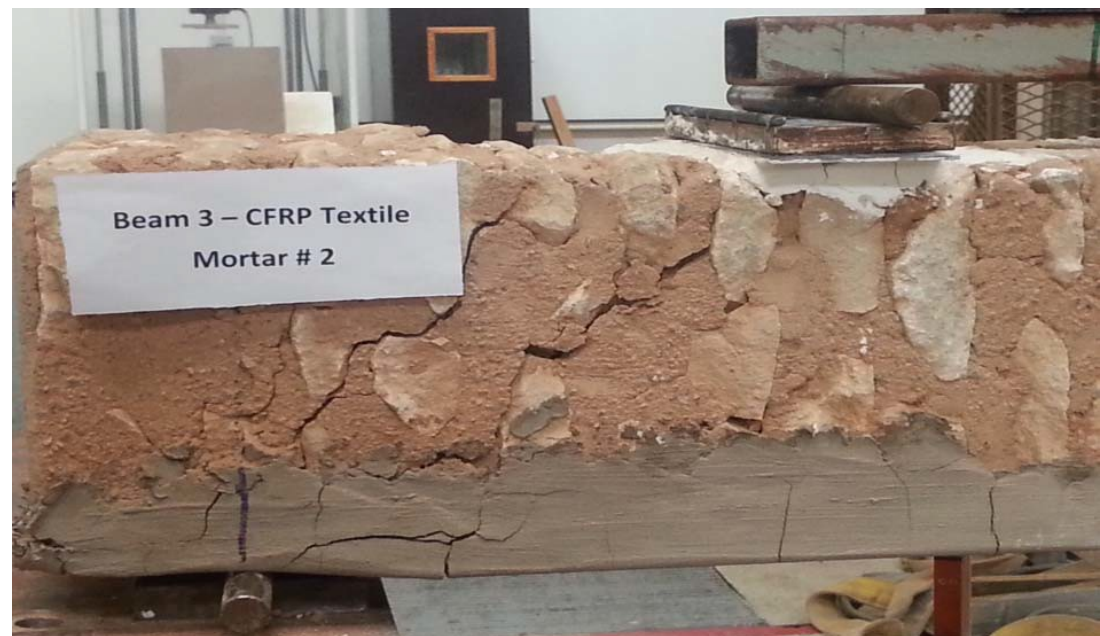

(c)

Figure 10. Shear failure: (a) Wall WGM1 replaced by, (b) Wall WGM2, and (c) Wall WCM2. 
out-of-plane or a bending load since the jointing mortar cannot resist tensile stresses. The mass of each wall was measured to be approximately $250 \mathrm{~kg}$ on average, resulting in a self-weight of $2.45 \mathrm{kN}$.

Therefore, an unreinforced wall was assumed to fail in a brittle manner even under its own weight when subjected to tensile stresses due to out-of-plane loading. It must be mentioned here that no control specimen in the form of an unreinforced wall was tested as it was already known that it would have crumbled into pieces due to tensile stresses once it was tilted to one side (i.e. laid horizontally) as was the case in testing the strengthened walls. As shown in Fig. 9, WGM1 reached an ultimate load of $6.95 \mathrm{kN}$ corresponding to a 25.2-mm mid-span deflection. WGM2 reached an ultimate load of $7.05 \mathrm{kN}$ corresponding to a mid-span deflection of $8.8 \mathrm{~mm}$. WCM2 reached an ultimate load of $8.35 \mathrm{kN}$ at a mid-span deflection of $20.3 \mathrm{~mm}$. The overall deflections at failure in the three walls specimens were $28 \mathrm{~mm}, 32 \mathrm{~mm}$, and 35 mm for WGM2, WGM1, and WCM2, respectively. Each strengthened wall was able to reach an ultimate load in addition to its own weight of $2.45 \mathrm{kN}$. Compared to an unreinforced wall which, it was assumed, would have failed under its own weight of 2.45 $\mathrm{kN}$, the increase in ultimate load capacity with respect to the unreinforced wall were $383 \%$, $387 \%$, and $440 \%$ in walls WGM1, WGM2, and WCM2, respectively. The same argument can be made about the deflection of strengthened walls compared to unreinforced walls, which would have failed in a brittle manner without any deformation under just its own weight. It must be mentioned here that given the fact that the Sarooj jointing mortar has better strength, the performance of the strengthened walls was expected to be much better. As reported by AlAl-Rawas et al. (1998), the Sarooj produced at other locations in Oman possessed better properties with much higher strength than the Sarooj from Nakhal and Wadi Al Mawal. The results obtained in this study clearly show the effectiveness of this strengthening technique even with very low-strength Sarooj jointing mortar.

It was noted that the cracks in wall WGM1 started at a lower load of $5.3 \mathrm{kN}$ compared to 7 $\mathrm{kN}$ when the cracks appeared in wall WGM2 (Figure $10 \mathrm{a}$ and b). In addition, wall WCM2 resisted a slightly higher load than WGM2.
Nonetheless, the main failure was due to shear in the jointing mortar and, therefore, it is very difficult to make a fair comparison on the effect of the matrix mortar M1 and M2 as well as the effect of the glass fiber textile in comparison with the effect of carbon fiber textile. In other words, both strengthening schemes would work since the weakness was in the jointing mortar rather than the TRM layer.

\subsection{Strengthened Column Specimens}

Column specimens were tested under axial compression. The load versus column top displacement is shown in Fig. 11. The control column (CC) reached an ultimate compression load of $37.30 \mathrm{kN}$ at a displacement of $8.8 \mathrm{~mm}$ (Fig. 11 and Table 4). Initially the response of the column showed an increase in displacement without a corresponding increase in load. This behavior may be attributed to the low-strength Sarooj jointing mortar. The load then picked up once the jointing mortar between the stone layers could not be further compressed and the stone layers became effective in the load carrying mechanism. Upon reaching the ultimate load, longitudinal cracks started to develop in the column sides as a result of the lateral tensile stress or Poisson's effect (Fig. 12). The cracks then enlarged and expanded until separation in the masonry column occurred and portions of the columns collapsed, causing brittle failure of the column.

The strengthened column (CCM2) showed superior performance from the start due to the confining effect of the textile reinforced mortar (TRM) jacket around the column (Fig. 11). It has been reported by many studies (Saadatmanesh et al.1994; Shirmohammadi et al. 2015) that using steel jackets or FRP wrapping around reinforced concrete column leads to a multifold increase in the axial load in

Table 4. Summary of test results.

\begin{tabular}{lccc}
\hline $\begin{array}{l}\text { Desig- } \\
\text { nation }\end{array}$ & $\begin{array}{l}\text { Maximu } \\
\mathrm{m} \text { Load } \\
(\mathrm{kN})\end{array}$ & $\begin{array}{c}\text { Deflection } \\
\text { @Max. } \\
\text { Load } \\
(\mathrm{mm})\end{array}$ & $\begin{array}{c}\text { Maxi- } \\
\text { mum } \\
\text { Deflection } \\
(\mathrm{mm})\end{array}$ \\
\hline WGM1 & 6.95 & 25.2 & 28 \\
WGM2 & 7.05 & 8.8 & 32 \\
WCM2 & 8.35 & 20.3 & 35 \\
CC & 37.3 & 8.8 & 15 \\
CCM2 & 262.8 & 26.2 & 35 \\
\hline
\end{tabular}




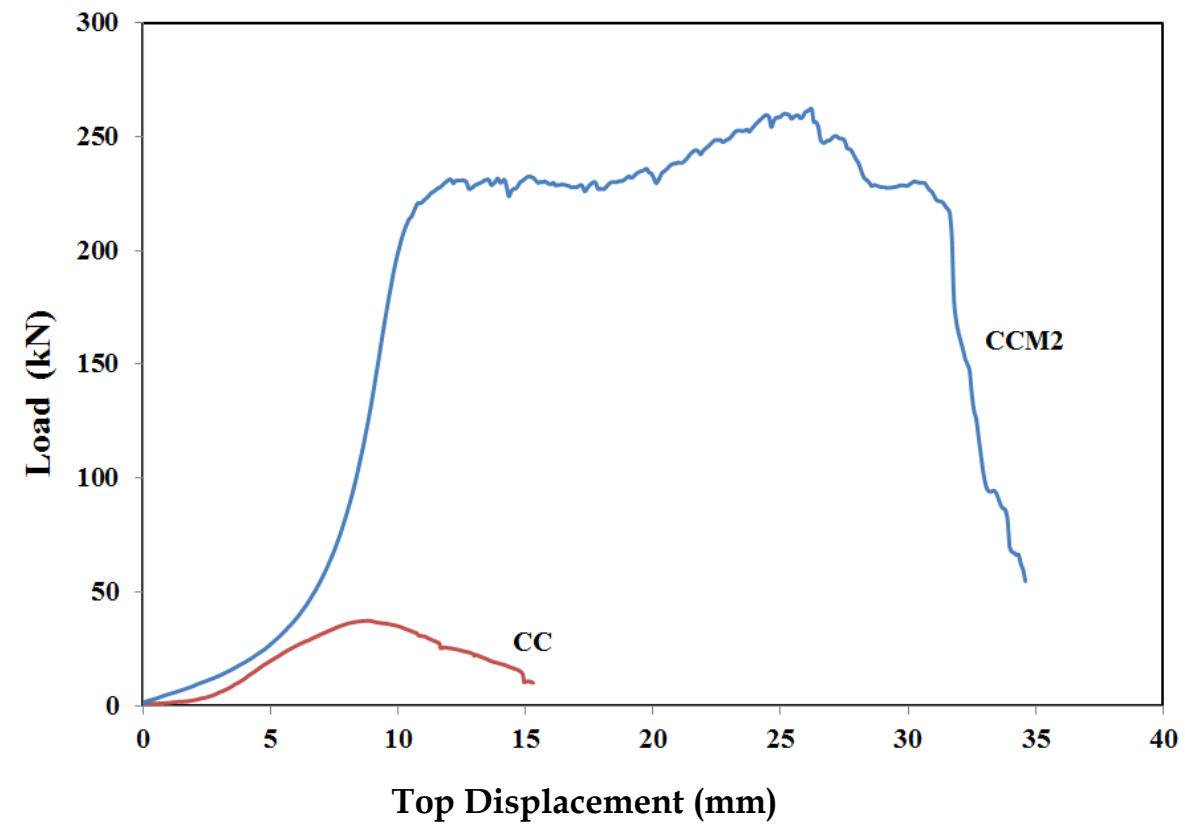

Figure 11. Load versus top displacement for columns CC and CCM2.

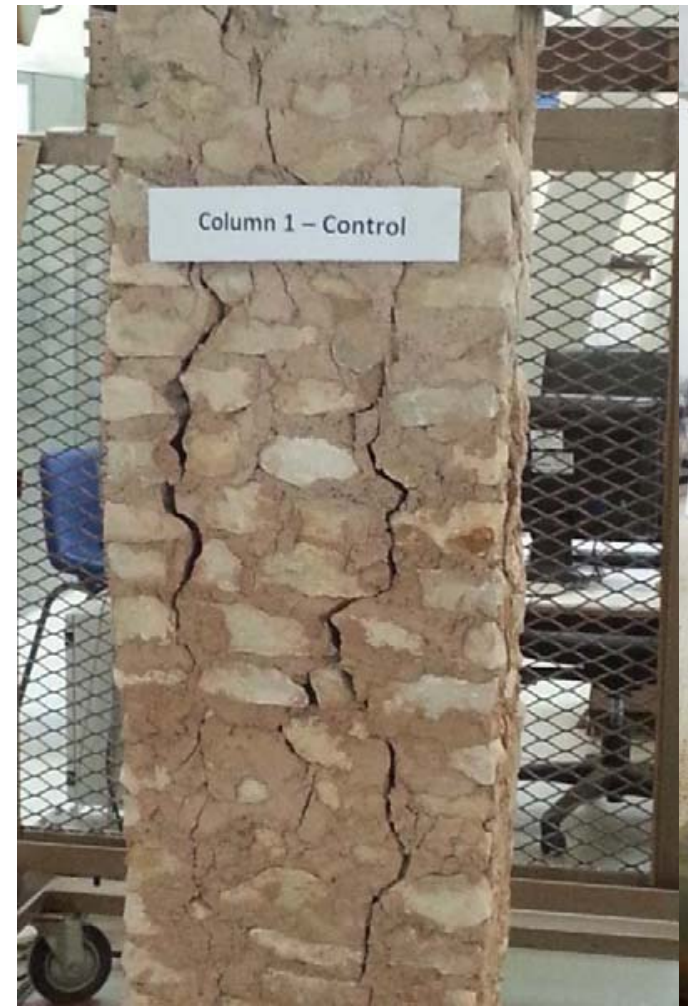

(a)

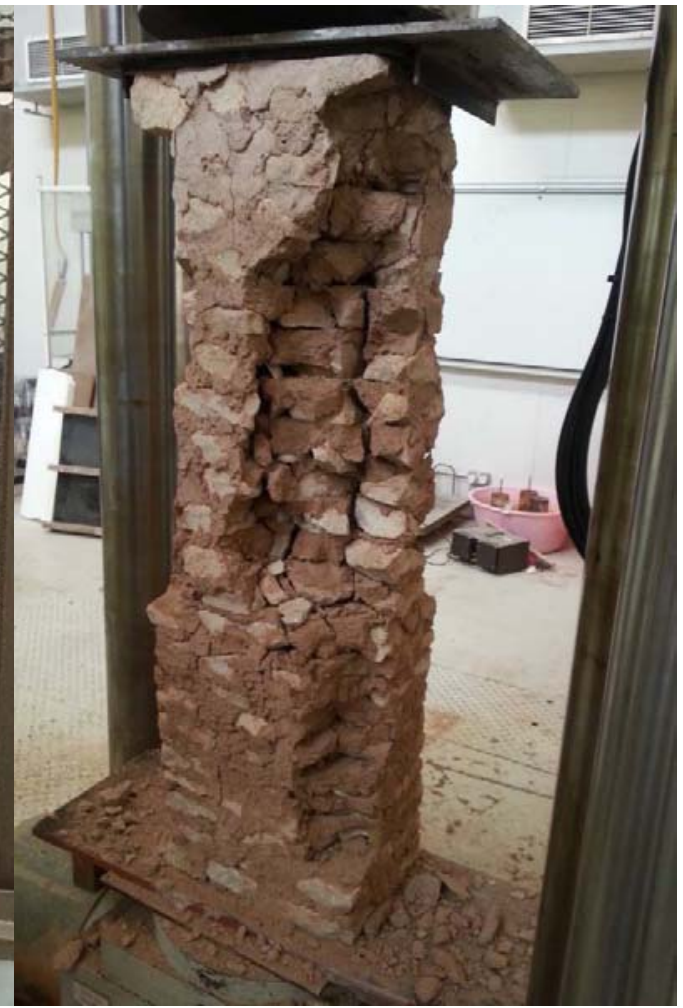

(b)

Figure 12. Column CC: (a) Longitudinal cracks development, and (b) At failure of column.

capacity due to the hoop stresses developed by the jacket around the column which applies a confining stresses responsible for an increase in the axial stress capacity. Column CCM2 reached an ultimate compression load of 262.8
$\mathrm{kN}$ at a corresponding top displacement of 26.2 $\mathrm{mm}$. The failure was initiated by cracks which developed at the column sides followed by the outer plaster layer peeling off. The inner plaster layer then started to crumble at the top 


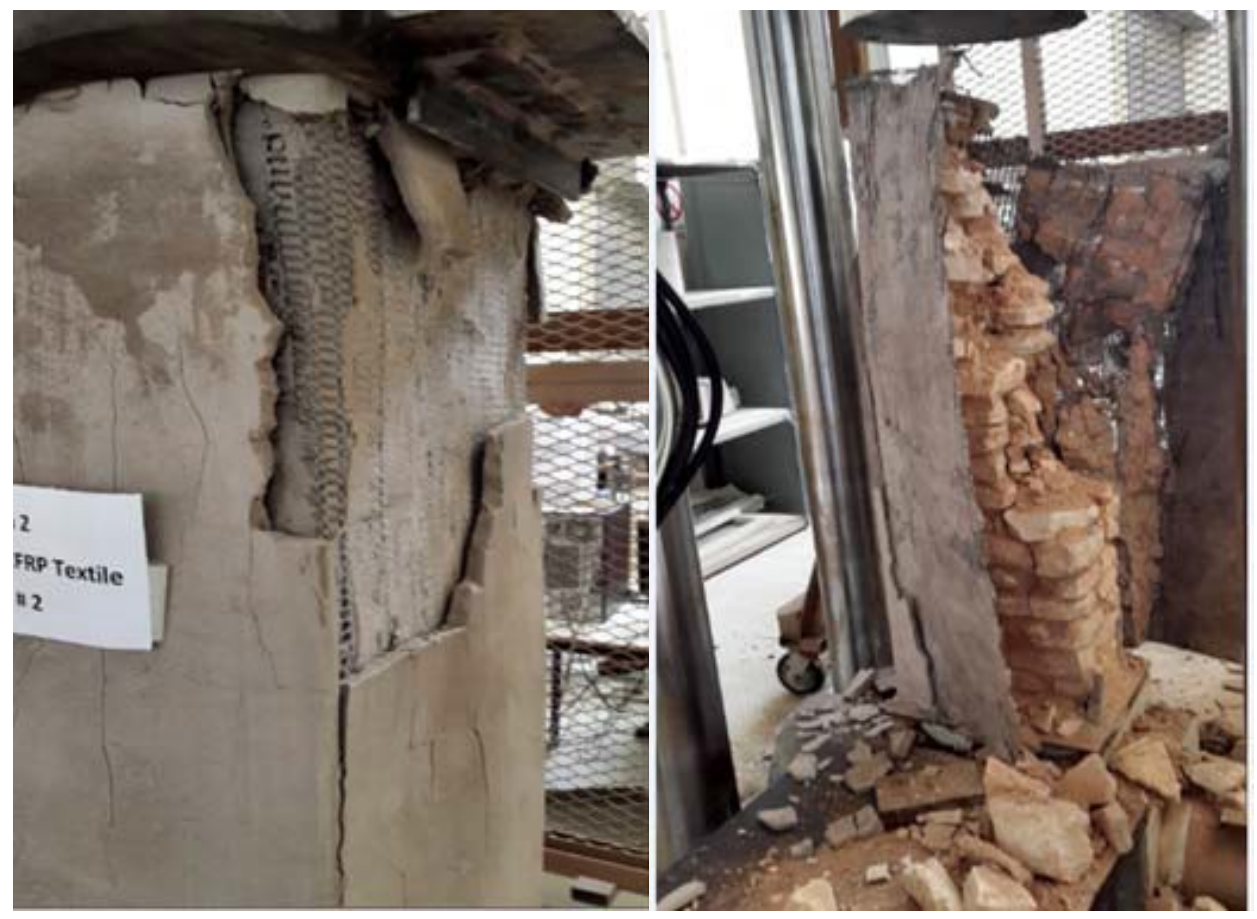

(a)

(b)

Figure 13. Column CCM2; (a) Outer mortar layer peeled off; (b) TRM jacket opened up at the overlapping and failure of the column.

of the column as the masonry expanded in the transverse direction and due to the high compressive stress at this stage. The textile started to rupture at one of the column edges in a localized manner due to stress concentration at the corners. The TRM jacket finally debonded at the overlap, causing the wrapping to open up and leading to the column's partial collapse (Fig. 13). Comparing the response of the CC and the CCM2 shows a considerable improvement in both the axial load capacity as the CCM2 was seven times that of the CC and reflected a $600 \%$ increase in the axial load capacity. Similarly, the displacement at the ultimate load attained in CCM2 was 3.2 times that of the CC, or a $216 \%$ increase, indicating an increase in the ductility of the strengthened column. Due to the failure of the wrapping at the overlapping part, it is recommended to extend the overlap to cover the entire face of the column in which the wrapping of the textile has started.

\section{Conclusion}

The presented experimental work is a pilot study to investigate the efficiency of a new strengthening technique using textilereinforced Sarooj mortar for the rehabilitation of plain stone masonry structures. The study included strengthening plain stone masonry walls for out of plane loading and full wrapping of stone masonry columns subjected to axial compression. Based on the presented experimental work, the following remarks are drawn:

- When subjected to out-of-plane bending, all the wall specimens failed due to diagonal shear failure, which can be attributed to the weak strength of the jointing Sarooj mortar.

- All strengthened masonry walls were able to resist 3-4 times their own weight or a $300-400 \%$ increase in the load-carrying capacity compared to unstrengthened masonry walls.

- All strengthened walls showed a ductile behavior before failure compared to the brittle failure of a plain masonry wall.

- Plain stone masonry columns failed in a brittle manner because of the low strength 
jointing mortar and due to lateral tensile stresses caused by Poisson's effect.

- Strengthening masonry columns by full wrapping with textile reinforced mortar resulted in a $600 \%$ and $130 \%$ strength and ductility improvement, respectively, compared to the reference column.

\section{References}

Al-Mashani, A (1997), Traditional construction in Dhofar. 1st ed, in Arabic.

Al-Rawas A, Hago A, Corcoran T and Al Ghafri K (1998), Properties of Omani artificial pozzolana (Sarooj). Applied Clay Science 13: 275-292.

Al-Rawas A and Hago A (2006), Evaluation of field and laboratory produced burnt clay pozzolans. Applied Clay Science 31: 29- 35.

American Society for testing and materials, ASTM C 114-13, standard test methods for chemical analysis of hydraulic cement.

American Society for testing and materials, ASTM C 25-11, standard test methods for chemical analysis of limestone, quicklime and hydrated lime.

American Society for testing and materials, ASTM C51, 2011. Standard terminology relating to lime and limestone (as used by the Industry).

American Society for testing and materials, ASTM C618 (1980), Specifications for fly ash and raw or calcined natural pozzolana for use as a mineral admixture in Portland cement. 375-378.

American Society for testing and materials, ASTM D5034-09, 2013, Standard test method for breaking strength and elongation of textile fabrics (Grab Test).

American Society for testing and materials, ASTM D6473, 2010, Standard test method for specific gravity and absorption of rock for erosion control.

American Society for testing and materials, ASTM D7012, 2004, Standard test methods for compressive strength and elastic moduli of intact rock core specimens under varying states of stress and temperatures.

Bernat-Maso E, Escrig C, Aranha C and Gil L (2014), Experimental assessment of textile reinforced sprayed mortar. Construction and Building Materials 50: 226-236.

Ehsani M R, Saadatmanesh H, Al-Saidy A (1997), Shear behavior of URM retrofitted with FRP overlays. Journal of Composites. for Construction 2(1): 17-25.

Hago A, Al-Rawas A (1997), Properties of the Omani Sarooj. Engineering Journal of University of Qatar 10: 81-91.

Hago A, Al-Rawas A, Al-Sidairi A (2002a), Effect of the fineness of artificial pozzolana (Sarooj) on the properties of limepozzolana mixes. Science and Technology 7: 251-258.

Hago A, Al-Rawas A, Al-Riyami A (2002b), Effect of varying cement content and curing conditions on the properties of Sarooj. Building and Environment 37: 45-53.

Harajli M, ElKhatib H, San-Jose J (2010), Static and cyclic out-of-plane response of masonry walls. Journal of Materials in Civil Engineering 22(11): 1171-1180.

Kolsch H (1998), Carbon fiber cement matrix (CFCM) overlay system for masonry strengthening. Journal of Composites for Construction 2:105-109.

Ministry of Heritage and Culture, Office of Deputy Minister for Ministry Affairs (1994), Forts and Castles in Oman. Sultanate of Oman: Studies Department, in Arabic.

Papanicolaou C, Triantafillou T, Lekka M (2011), Externally bonded grids as strengthening and seismic retrofitting materials for masonry panels. Construction and Building Materials 25: 504-514.

Pinho F, Luco V, Baiao M (2014), Rubble stone masonry walls strengthened by threedimensional steel ties and textile reinforced mortar render under compression. International Journal of architectural Heritage 8(5): 670-689.

Saadatmanesh H, Ehsani M, Li M (1994), Strength and ductility of concrete columns externally reinforced with fiber composite straps. ACI Struct. Journal. 91(4): 434-447. Shirmohammadi F, Esmaeily A, Kiaeipour Z (2015), Stress-strain model for circular concrete columns confined by FRP and conventional lateral steel. Engineering Structures 84: 395-405.

Triantafillou T (1998), Strengthening of masonry structures using epoxy-bonded 
FRP laminates. Journal of Composites for Construction 2: 96-104.
Varshney RS (1982), Concrete technology. Oxford: IBH Company. 